(C) 2016, Elsevier. Licensed under the Creative Commons Attribution-NonCommercial-NoDerivatives 4.0 International http://creativecommons.org/licenses/by-nc-nd/4.0/

On the Relationship between Cultural Diversity and Creativity in Education: The Moderating Role of Communal versus Divisional Mindset

\author{
Loris Vezzali \\ University of Modena and Reggio Emilia
}

Malgorzata Goclowska

University of Amsterdam

Richard J. Crisp

University of Aston

Sofia Stathi

University of Greenwich

Correspondence concerning this article should be addressed to Loris Vezzali,

Dipartimento di Educazione e Scienze Umane, viale Allegri 9, 42121, Reggio Emilia, Italy. E-mail: loris.vezzali@unimore.it

Tel: + 390522 523006. Fax: +390522523055

\title{
Acknowledgments
}

We would like to thank Paola Spagnol and the other teachers for their help in the organization of the study. A special thank is for Omayra Prampolini and Diletta Ronzoni, who worked as research assistants. We are also grateful to the Institutes Frank, Giotto and Pertini (Carpi) for allowing us to run the study and collect data. 


\title{
On the Relationship between Cultural Diversity and Creativity in Education:
}

The Moderating Role of Communal versus Divisional Mindset

\begin{abstract}
We conducted an experimental study with the aim of testing certain conditions under which engaging with cultural diversity increases creativity among schoolchildren. Results obtained from a sample of 149 Italian elementary schoolchildren revealed that engaging with cultural diversity, operationalized by asking Italian children to work with immigrant children on a cooperative task, led to an increase in creativity. Furthermore, we found that this effect was only present when a communal but not a divisional mindset (emphasizing group distinctions) was present. We discuss theoretical and practical implications of findings.
\end{abstract}

Keywords: flexible thinking; creativity; cultural diversity; intergroup contact; intergroup processes; diversity climate; diversity in education. 


\section{On the Relationship between Cultural Diversity and Creativity in Education: The Moderating Role of Communal versus Divisional Mindset}

Creative products are novel and useful (Amabile, 1983), and creativity emerges when people think in a flexible or persistent way (Schank \& Abelson, 1977; for a review, see Nijstad, De Dreu, Rietzschel, \& Baas, 2010) and are highly motivated (Amabile, Hill, Hennessey, \& Tighe, 1994). Creativity is essential in organizations (Lombardo \& Roddy, 2010), and the fostering of creative thinking in some educational systems, such as in England, is encouraged from a young age (Education, 1999). Recent evidence suggests that creativity can be encouraged through social diversity (Crisp \& Turner, 2011), but while well tested in adult population, this idea is yet to be investigated with regard to schoolchildren. The aim of this study was to examine whether diversity increases creativity among schoolchildren, and what boundary conditions may eventually prevent the positive effects of diversity on creativity.

\section{Diversity and Creativity}

Diversity disrupts the extent to which people use stereotypes and cognitive schemas during problem solving (for reviews, see Crisp \& Turner, 2011; Gocłowska \& Crisp, 2013), allowing people to engage in more generative thought (Gocłowska, Crisp, \& Labuschagne, 2013). It can also increase the amount of ideas that are available for input (Leung \& Chiu, 2010), and helps individuals to see the same problems from multiple perspectives (for an overview see Leung, Maddux, Galinsky, \& Chiu, 2008; Tadmor \& Tetlock, 2009).

The benefits of diversity have been observed across various levels of analysis. Archival studies indicated that the influx of foreign ideas and people stimulated country-level innovation two generations later (Simonton, 1997), and that eminent 
individuals, more often than their contemporaries, came from immigrant families, or have themselves experienced migration (Simonton, 1999). A study of $20^{\text {th }}$ century eminent personalities found that $20 \%$ of the analyzed creators were either first- or secondgeneration immigrants (Goertzel, 1978). And although foreign-born individuals comprise only $13 \%$ of the U.S. population, they account for $30 \%$ of all the patents granted, and for $25 \%$ of all the U.S. Nobel Laureates (Peri, 2012).

In cross-sectional studies biculturalism (Tadmor \& Tetlock, 2009), bilingualism (Benet-Martínez, Lee, \& Leu, 2006) and even membership in multiple social groups were associated with greater creativity (Steffens, Gocłowska, Cruwys, \& Galinsky, 2016). For instance, the ideas of bicultural individuals (vs. those who identify with one culture only) tend to be more novel and original (Fee \& Gray, 2012; Kharkhurin, 2011; Tadmor, Galinsky, \& Maddux, 2012), their negotiation solutions are more creative (Maddux \& Galinsky, 2009), and their work performance is rated as more innovative (Tadmor et al., 2012).

In experimental studies, thinking of diverse individuals (e.g., gender counterstereotypes, Gocłowska et al., 2013) and exposure to symbols and ideas from multiple cultures were found to elicit greater creative performance (Leung \& Chiu, 2010). Finally, longitudinal research has confirmed that the effects of social diversity on creativity are causal: international aid workers from Australia and New Zealand, who were delegated to work in another country (measured against the pre-departure baseline, and against non-expatriates), experienced an increase in creative ability 12 months following departure (Fee \& Gray, 2012). Taken together, these studies suggest that engaging with diversity can lead to enhanced creative performance (see Crisp \& Turner, 2012; Gocłowska \& Crisp, 2015, for reviews). These findings generate Hypothesis 1: that diversity in an educational classroom promotes pupils' creativity. 


\section{Moderators of the Diversity-Creativity Link}

It is important to note that despite the growing support for a diversity-creativity link, the effects of diversity are not unmoderated. For instance, diversity is less likely to benefit creative idea generation when need for structure is high (Gocłowska, Baas, Crisp, \& De Dreu, 2014; Gocłowska \& Crisp, 2013), when people are closed for new experiences (Leung \& Chiu, 2008), hold negative diversity beliefs (Homan, van Knippenberg, Van Kleef, \& De Dreu, 2007) or feel pressured for time, or threatened (Leung \& Chiu, 2010). In addition, a social categorization perspective on diversity would argue that similarities and differences between group members, that are used to categorize self and others into "us" and "them," can disrupt the beneficial effect of social diversity. This is because people typically like and trust ingroup members more than outgroups members (Brewer, 1979; Tajfel, 1982; Turner, Hogg, Oakes, Reicher, \& Wetherell, 1987), and a perception of salient intergroup divisions may lead them to take a more resistant and defensive stance, a "divisional mindset" that undermines cognitive functioning (Richeson \& Trawalter, 2005; van Knippenberg, De Dreu \& Homan, 2004). Such a divisional mindset, which is focused on group distinctions, may disrupt the beneficial effects of diversity, by activating intergroup differentiation processes which are at odds with the original way of thinking prompted by diversity. Because of this, the salience of diversity faultlines, that is, clear intergroup divisions, may block the beneficial effects of group diversity on creativity. We therefore posit Hypothesis 2a: we should observe greater creativity when a communal mindset (which does not mention group differences) is salient, and Hypothesis $2 \mathrm{~b}$ : that exposure to diversity will not produce more original ideas when a divisional mindset is activated. 


\section{The Present Research}

The aim of this study was to test whether diversity promotes creativity among children (Hypothesis 1), and whether this positive effect of creativity would be observed when a communal (Hypothesis $2 \mathrm{a}$ ) but not when a divisional mindset (Hypothesis $2 \mathrm{~b}$ ) is salient. To test these hypotheses, we ran an experimental intervention with Italian elementary school children, assigned to work in diverse cultural groups (together with immigrant peers), or in homogeneous groups (composed only of Italians) on a cooperative task requiring them to create a story. Orthogonal to the diversity manipulation, we manipulated the prevailing mindset. Participants in each small group were asked to imagine being affiliated to one of two distinct minimal categories (thus activating a divisional mindset focused on group differences), or co-operating with one another within the same minimal group (thus activating a co-operative, communal mindset, where group distinctions were less salient). Children took part in three intervention sessions; one week after the last session, they were administered a measure of creativity (i.e. originality).

\section{Method}

\subsection{Participants and experimental design}

Participants comprised 149 Italian elementary school children (73 males, 76 females); mean age was 9 years 11 months. ${ }^{1}$ Participants were randomly allocated to one of the four cells of a 2 (Diversity: present vs. absent) $\times 2$ (Mindset: divisional vs. communal) between-subjects experimental design.

\subsection{Procedure}

Children were randomly allocated by experimenters to form same-sex groups each comprising 3 to 6 children. The choice to consider same-sex groups was taken in 
order to avoid potential effects of an additional group variable (gender), which would be beyond the scope of this research. Participants were asked to imagine a story where they impersonated characters whose aim was to cooperate in order to survive in a fantasy scenario. To manipulate diversity, we varied the ethnic composition of small groups: in the condition where diversity was present, children were both Italian and immigrant; in the condition where diversity was absent, children were all Italian.

The manipulation of mindset was orthogonal to the diversity manipulation. In the communal mindset condition, participants imagined impersonating characters from the fictional planet Astra. Participants were told that inhabitants of Astra had blue skin, were generous, nice, respecting Nature; they were athletic and two meters tall. According to the background story, Astra was a green planet that was sufficient for everyone's survival. However, suddenly terrible things happened on the planet Astra: the waters, trees and flowers were poisoned. The task of participants was to create a story in which the inhabitants worked to identify the cause of what was happening to Astra, counter-act the disaster, and travel around the planet to experience new adventures. The story was identical in the communal and in the divisional mindset condition except that in the divisional mindset condition participants imagined the story featuring two opposing groups, Sun and Moon, who had a different skin color (yellow for the Sun and blue for the Moon), and distinct magic powers.

Each small group met once a week for three consecutive weeks to enact the roles of the blue (in communal mindset condition) or blue and yellow (in divisional mindset condition) inhabitants of Astra. One week after the last session, participants were administered the dependent measure. ${ }^{2}$ 


\subsection{Measure}

Creativity. Participants were asked to work on an individual task that required them to identify alternative uses for an object; a method aimed at measuring divergent thinking (Gilhooly, Fioratou, Anthony, \& Wynn, 2007; Guilford, 1967; Kharkhurin, 2009). Specifically, each child was asked to write down all the different uses of a plastic bottle that came to their mind. Two raters (students enrolled in educational academic courses at a Northern Italian university) blind to our hypotheses coded participants' responses into 10 different categories (e.g., recycling, playing, container, etc.). Originality was then inferred by calculating the percentage of participants mentioning the same use of the plastic bottle (see Amabile, 1983; De Dreu, Nijstad, \& Baas, 2011; Gocłowska \& Crisp, 2012; Guilford, 1967; Torrance, 1974). To obtain originality scores, we used the following equation (see Gocłowska \& Crisp, 2012): 1 - (percentage of participants who generated the same idea/100). For instance, if $80 \%$ of participants mentioned that a plastic bottle can be used to drink, the resulting originality score is $0.20(20 \%)$. For each participant, frequency scores for each idea were summed and then divided by the number of ideas generated by that participant. Scores thus can range from 0.0 (low originality) to 1.0 (high originality). ${ }^{3}$

\section{Results}

To test our hypotheses, we conducted a 2 (Diversity: present vs. absent) $\times 2$ (Mindset: communal vs. divisional) between-subjects ANOVA. Means and standard deviations of creativity in the four cells of the experimental design are presented in Table 1. Creativity was square-root transformed to approximate normality (Field, 2013); for ease of presentation, the means and the standard deviations presented in the text and in the Table refer to nontransformed data. 
Consistent with Hypothesis 1, stating that diversity should promote greater creativity, the ANOVA revealed a main effect of Diversity, $F(1,50)=5.84, p=.017$, $\eta_{\mathrm{p}}^{2}=.04$ : creativity was higher among participants in the condition where diversity was present $(M=0.56 ; S D=0.08)$ than among those in the condition where diversity was absent $(M=0.51 ; S D=0.12)$. Moreover, the two-way interaction was significant, $F(1$, $145)=4.68, p=.032 \eta_{p}^{2}=.03$. Analyses of simple effects showed that, consistent with Hypothesis 2a, the presence of diversity increased creativity when participants were exposed to a communal mindset, $F(1,145)=10.06, p=.002, \eta^{2}{ }_{p}=.06$; in line with Hypothesis $2 b$, however, when the mindset was based on divisions, the effect of diversity was nonsignificant, $F<1$ (see Table 1 ).

\section{Discussion}

In this article we present an experimental study aimed at testing whether diversity increases creativity among schoolchildren. Our first hypothesis was that diversity would promote greater creativity. Taking into account individuals' mindset, we also hypothesized that diversity would increase creativity when a communal (Hypothesis 2a) but not when a divisional mindset (Hypothesis 2b) was salient. Results were consistent with our hypotheses. First, in line with Hypothesis 1, creativity was higher for participants working in diverse cultural groups, compared to participants working with ingroup members (i.e. Italians). Second, participants' mindset moderated the effect of diversity, such that the effect of diversity only emerged when a communal mindset was salient (Hypothesis 2a); in contrast, diversity did not affect creativity when a divisional mindset, focusing on group differences, was activated (Hypothesis $2 \mathrm{~b}$ ).

To our best knowledge, these findings provide first direct experimental evidence that exposure to cultural diversity increases creativity among schoolchildren. By doing 
so, our study contributes to the growing body of evidence showing the beneficial effects of social diversity (Crisp \& Turner, 2011; Gocłowska \& Crisp, 2014; Leung et al., 2008), and extends the application of these findings to educational contexts.

Importantly, rather than using preexisting diverse or homogenous groups, as is common in diversity research (Davies, Tropp, Aron, Pettigrew, \& Wright, 2001), exposure to diversity in our study was manipulated, allowing for the elimination of potential confounding variables, such as pre-selection. In other words, we can exclude the alternative explanation that more creative children seek out more diverse friends, since participants were randomly allocated to conditions of presence or absence of diversity. In addition, our study used a novel, highly engaging manipulation. We did not simply allocate children to a diverse environment; rather, children were asked to work on a cooperative task. There is indeed evidence that interventions are more effective when participants are actively engaged (Oskamp, 2000). Moreover, positive effects of cross-cultural experiences are more likely to emerge when they happen under optimal conditions, such as working cooperatively for a superordinate goal in a supportive environment (Allport, 1954).

The second relevant finding is that the positive effect of diversity was nullified when a divisional mindset was salient. We argue that such a divisional mindset has activated differentiation processes typical of intergroup relations, whereby individuals favor ingroup members at the expense of outgroup members and rely to a greater extent on group stereotypes and pre-existing biases (Tajfel, 1982; Turner et al., 1987). Since these processes are at odds with the original way of thinking generated by diversity, which instead exerts its effects by disrupting stereotypes (Crisp \& Turner, 2011; Gocłowska \& Crisp, 2013), our results suggest that reminding participants of group 
divisions blocked the positive effects of diversity. In contrast, when a communal mindset was active (mindset manipulation), and participants actively and cooperatively worked with outgroup members (group diversity manipulation), the generation of novel and original ideas increased. This is the first study, to our knowledge, that experimentally tested whether a mindset focused on communalities versus divisions moderates the effects of diversity on creativity in children. Future studies should test whether other factors, such as need for structure (Gocłowska et al., 2014) or openness to new experiences (Leung \& Chiu, 2008), moderate the effect of diversity on schoolchildren's creativity.

It is worth noting that the disruptive effects of the divisional mindset were evident even though the story used to activate it featured a positive, co-operative outcome (i.e. working together to resolve a planetary disaster). This suggests that simply activating a divisional mindset, focused on salience of group distinctions, is sufficient to give rise to negative consequences associated with group categorization (Hewstone, Rubin, \& Willis, 2002), independently of its valence and of the positivity of the diverse experience. A further prediction is that the disrupting effects of a divisional mindset would be even more pronounced if salience of group distinctions was negative; for example, if individuals were reminded of competitive relations between groups.

One implication of our findings is that, in order for diversity to benefit creativity, group distinctions should not be salient. This finding is in contrast to research on prejudice reduction, where group salience is thought as a necessary precondition for diversity to reduce prejudice (Brown \& Hewstone, 2005). Importantly, however, the requirement for group salience in intergroup contact research is to reduce the identity threat associated with losing ingroup distinctiveness (Brown \& Hewstone, 2005). Here, 
we are not concerned with attitudinal outcomes that may be moderated by identity concerns, but the cognitive reconstrual processes that can elicit different ways of thinking beyond intergroup relations. Examining the interplay of identity, distinctiveness and diversity for different dependent measures (and for eliciting positive outcomes in different domains) may be an important focus for future work.

The present study has relevant practical implications. Educational interventions could take advantage of multicultural settings in order to foster creative thinking among schoolchildren. Importantly, our findings suggest that participants should be actively engaged in cooperative activities with members of different cultural groups, rather than being simply "exposed" to them. Moreover, we argue for the importance of communal mindset that does not make group differences salient.

We acknowledge a limitation of our experimental design. Although we believe that random allocation of participants to experimental condition should have reduced possible influences of initial differences between experimental groups, the fact that the dependent variable was only measured after the manipulation does not totally exclude this possibility. We note that administering the same task before the manipulation would have probably primed some responses on the potential use of a bottle (dependent variable) among participants, thus somewhat invalidating its use as a dependent variable. The alternative option of using a different creativity task before the manipulation would have been subject to limited comparability with the measure we used. In any case, we acknowledge that our experimental design could indeed have included a carefully designed pre-test measure.

Another weakness of the present study is that it does not provide evidence on the creative processes that lead to increased originality. Creativity is a function of multiple 
processes: people are creative when they think in a flexible manner (Gocłowska, Crisp, \& Labuschagne, 2013), when they persist on finding solutions to a concrete problem (Baas, De Dreu, \& Nijstad, 2011), when they feel greater intrinsic motivation (Amabile et al., 1994), or want to avoid unpleasant events (Baas et al., 2011). Since our study uncovered effects specifically to originality of ideas, it is not clear from the present set of results whether, as in other diversity research, this is caused by cognitive flexibility (i.e. the exploration of ideas across many semantic categories), or another process. Future studies focusing on constructs more closely related to flexibility - for instance integrative complexity, or cognitive complexity (Benet-Martínez, Lee, \& Leu, 2006; Tadmor \& Tetlock, 2009) - may resolve this issue. However, one important concern is that these measures must be adapted in a way that makes them suitable for administration to children.

In conclusion, we demonstrated that diversity can have positive effects on the development of creativity, and that the salience of intergroup divisions constitutes a boundary condition of these effects. School environments are critical for fostering children's creativity (Barak \& Mesika, 2007), and with increased social mobility and immigration, these environments are becoming increasingly culturally diverse. Thus, it is surprising that research on diversity and creativity among children is still nascent. More studies are needed to further explore the diversity-creativity link among children of various developmental ages, and to understand what mindsets and attitudes of students, as well as of teachers, are helpful in reaping the benefits of classroom diversity. 


\section{Footnotes}

1. There also were 51 immigrants. The distinction between Italian and immigrant children was performed on the basis of the schools' indications, taking into account the family background of children (i.e. whether children had immigrant parents). However, due to the small number of immigrant children and the unfeasibility to reach an acceptable sample size in the four experimental cells, analyses for immigrant children were not performed.

2. The results reported in this manuscript are derived from a larger dataset design to assess the impact of intergroup contact on a range of dependent measures. Results for other measures included in this dataset are not relevant to the hypotheses tested in the current article so we do not discuss them further. A description of some of these measures and a detailed account of the procedure can be found in Vezzali, Stathi, Crisp and Capozza (2015).

3. Since at least one participant mentioned each idea, both 0 and 1 are ideal points. The participants' actual scores in this study ranged from 0.19 to $0.77(M=0.53, S D=$ $0.10)$. 


\section{References}

Allport, G. W. (1954). The nature of prejudice. New York, NY: Addison-Wesley.

Amabile, T. M. (1983). The social psychology of creativity: A componential conceptualization. Journal of Personality and Social Psychology, 45, 357-376. doi:10.1037/0022-3514.45.2.357

Amabile, T. M., Hill, K. G., Hennessey, B. a, \& Tighe, E. M. (1994). The Work Preference Inventory: Assessing intrinsic and extrinsic motivational orientations. Journal of Personality and Social Psychology, 66, 950-967. doi: 10.1037//00223514.68 .4 .580

Baas, M., De Dreu, C. K. W., \& Nijstad, B. A. (2011). When prevention promotes creativity: The role of mood, regulatory focus, and regulatory closure. Journal of Personality and Social Psychology, 100, 794-809. doi: 10.1037/a0022981

Benet-Martinez, V., Lee, F., \& Leu, J. (2006). Biculturalism and cognitive complexity: Expertise in cultural representations. Journal of Cross-Cultural Psychology, 37, 386407. doi:10.1177/0022022106288476

Brewer, M. B. (1979). In-group bias in the minimal intergroup situation: A cognitivemotivational analysis. Psychological Bulletin, 86, 307-324. doi:10.1037//00332909.86.2.307

Brown, R., \& Hewstone, M. (2005). An integrative theory of intergroup contact. Advances in Experimental Social Psychology, 37, 255-343. doi: 10.1016/S00652601(05)37005-5

Crisp, R. J., \& Turner, R. N. (2011). Cognitive adaptation to the experience of social and cultural diversity. Psychological Bulletin, 137, 242-266. doi:10.1037/a0021840 
Crisp, R. J. \& Turner, R. N. (2012). The imagined contact hypothesis. Advances in Experimental Social Psychology, 46, 125-182. doi: 10.1016/B978-0-12-3942814.00003-9

Davies, K., Tropp, L. R., Aron, A., Pettigrew, T. F., \& Wright, S. C. (2011). Crossgroup friendships and intergroup attitudes: A meta-analytic review. Personality and Social Psychology Review, 15, 332-351. doi: 10.1177/1088868311411103

De Dreu, C. K. W., Baas, M., \& Nijstad, B. A. (2008). Hedonic tone and activation in the mood-creativity link: Towards a dual pathway to creativity model. Journal of Personality and Social Psychology, 94, 739-756. doi: 10.1037/0022-3514.94.5.739

De Dreu, C. K. W., Nijstad, B. A., \& Baas, M. (2011). Behavioral activation links to creativity because of increased flexibility. Social Psychological and Personality Science, 2, 72-80. doi: 10.1177/1948550610381789

Education, N. A. C. C. C. E. (1999). All our futures: Creativity, culture and education. London, UK.

Fee, A., \& Gray, S. J. (2012). The expatriate-creativity hypothesis: A longitudinal field test. Human Relations, 65, 1515-1538. doi: 10.1177/0018726712454900

Field, A. (2013). Discovering Statistics Using IBM SPSS Statistics. And sex and drugs and rock " $n$ " roll. London, UK: Sage.

Gilhooly, K. J., Fioratou, E., Anthony, S. H., \& Wynn, V. (2007). Divergent thinking: Strategies and executive involvement in generating novel uses for familiar objects. British Journal of Psychology, 98, 611-625. doi: 10.1111/j.20448295.2007.tb00467.x 
Gocłowska, M. A., Baas, M., Crisp, R. J., \& De Dreu, C. K. W. (2014). Whether social schema violations help or hurt creativity depends on need for structure. Personality and Social Psychology Bulletin, 40, 959-971. doi:10.1177/0146167214533132

Gocłowska, M. A., \& Crisp, R. J. (2012). On counter-stereotypes and creative cognition: When interventions for reducing prejudice can boost divergent thinking. Thinking Skills and Creativity, 8, 72-79. doi:10.1016/j.tsc.2012.07.001

Gocłowska, M. A., Crisp, R. J., \& Labuschagne, K. (2013). Can counter-stereotypes boost flexible thinking? Group Processes and Intergroup Relations, 16, $217-231$. doi:10.1177/1368430212445076

Goertzel, M. G. (1978). 300 eminent personalities: A psycho social analysis of the famous. San Francisco, CA: Jossey-Bass.

Guerra, R., Rebelo, M., Monteiro, M. B., Riek, B. M., Mania, E. W., Gaertner, S. L., \& Dovidio, J. F. (2010). How should intergroup contact be structured to reduce bias among majority and minority group children? Group Processes and Intergroup Relations, 13, 445-460. doi: 10.1177/1368430209355651

Guilford, J. P. (1967). The nature of human intelligence. New York, NY: McGraw-Hill. Harwey, S. (2013). A different perspective: The multiple effects of deep level diversity on group creativity. Journal of Experimental Social Psychology, 49, 822-832. doi: 10.1016/j.jesp.2013.04.004.

Hewstone, M., Rubin, M., \& Willis, H. (2002). Intergroup bias. Annual Review of Psychology, 53, 575-604. doi: 10.1146/annurev.psych.53.100901.135109

Hodson, G., \& Hewstone, M. (Eds.) (2013). Advances in intergroup contact. New York, NY: Psychology press. 
Hogg, M. A. (2007). Uncertainty-identity theory. Advances in Experimental Social Psychology, 39, 69-126. doi:10.1016/S0065-2601(06)39002-8

Homan, A. C., van Knippenberg, D., Van Kleef, G. A., \& De Dreu, C. K. W. (2007). Bridging faultlines by valuing diversity: Diversity beliefs, information elaboration, and performance in diverse work groups. Journal of Applied Psychology, 92, 11891199. doi:10.1037/0021-9010.92.5.1189

Kharkhurin, A. V. (2009). The role of bilingualism in creative performance on divergent thinking and invented alien creatures tests. Journal of Creative Behavior, 43, 59-71. doi: 10.1002/j.2162-6057.2009.tb01306.x

Kharkhurin, A. V. (2011). Conceptual freedom of the globalized mind. Multicultural experiences enhance human cognition through the expansion of conceptual categories. Journal of Consciousness Studies, 18, 66-83.

Leung, K. Y., \& Chiu, C. -Y. (2008). Interactive effects of multicultural experiences and openness to experience on creative potential. Creativity Research Journal, 20, 376-382. doi:10.1080/10400410802391371

Leung, K. Y., \& Chiu, C. -Y. (2010). Multicultural experience, idea receptiveness, and creativity. Journal of Cross-Cultural Psychology, 41, 723-741. doi: $10.1177 / 0022022110361707$

Leung, A. K.-Y., Maddux, W. W., Galinsky, A. D., \& Chiu, C.-Y. (2008). Multicultural experience enhances creativity: the when and how. The American Psychologist, 63, 169-181. doi: 10.1037/0003-066X.63.3.169

Lombardo, B. J., \& Roddy, D. J. (2010). Cultivating organizational creativity in an age of complexity. A companion study to the IBM 2010 Global Chief Human Resource 
Officer Study. Retrieved from: http://

public.dhe.ibm.com/common/ssi/ecm/en/gbe03418usen/GBE034 18USEN.PDF

Maddux, W. W., \& Galinsky, A. D. (2009). Cultural borders and mental barriers: The relationship between living abroad and creativity. Journal of Personality and Social Psychology, 96, 1047-1061. doi: 10.1037/a0014861

Nijstad, B. A., De Dreu, C. K. W., Rietzschel, E. F., \& Baas, M. (2010). The dual pathway to creativity model: Creative ideation as a function of flexibility and persistence. European Review of Social Psychology, 21, 34-77. doi:

$10.1080 / 10463281003765323$

Oskamp, S. (2000). Reducing prejudice and discrimination. Mahawah, NJ: Erlbaum.

Peri, G. (2012). The effect of immigration on productivity: Evidence from U.S. states. Review of Economics and Statistics, 94, 348-358. doi: 10.3386/w15507

Pettigrew, T. F., \& Tropp, L. R. (2006). A meta-analytic test of intergroup contact theory. Journal of Personality and Social Psychology, 90, 751-783. Doi $: 10.1037 / 0022-3514.90 .5 .751$

Richeson, J. A., \& Shelton, J. N. (2003). When prejudice does not pay: Effects of interracial contact on executive function. Psychological Science, 14, 287-290. doi: $10.1111 / 1467-9280.03437$

Richeson, J. A., \& Trawalter, S. (2005). Why do interracial interactions impair executive funcions. A resource depletion account. Journal of Personality and Social Psychology, 88, 934-947. doi: 10.1037/0022-3514.88.6.934

Schank, R., \& Abelson, R. (1977). Script, plans, goals and understanding: An inquiry into human knowledge structures. Hillsdale, NJ: Erlbaum. 
Simonton, D. K. (1997). Foreign influence and national achievement: The impact of open milieus on Japanese civilization. Journal of Personality and Social Psychology, 72, 86-94. doi: 10.1037/h0082846

Steffens, N. K., Gocłowska, M. A., Cruwys, T., \& Galinsky, A. D. (2016). How multiple social identities are related to creativity. Personality and Social Psychology Bulletin, 42, 188-203. doi: 10.1177/0146167215619875

Sligte, D. J., de Dreu, C. K. W., \& Nijstad, B. A. (2011). Power, stability of power, and creativity. Journal of Experimental Social Psychology, 47, 891-897. doi:

10.1016/j.jesp.2011.03.009

Tadmor, C. T., Galinsky, A. D., \& Maddux, W. W. (2012). Getting the most out of living abroad: Biculturalism and integrative complexity as key drivers of creative and professional success. Journal of Personality and Social Psychology, 103, 520542. doi: $10.1037 / \mathrm{a} 0029360$

Tadmor, C. T., \& Tetlock, P. E. (2009). Acculturation strategies and integrative complexity: The cognitive implications of biculturalism. Journal of Cross-Cultural Psychology, 40, 105-139. doi: 10.1177/0022022108326279

Tajfel, H. (1982). Social psychology of intergroup relations. Annual Review of Psychology. 33, 1. doi: 10.1146/annurev.ps.33.020182.000245

Torrance, E. P. (1974). Torrance test of creative thinking. Lexington, MA: Personal Press.

Turner, J. C., Hogg, M. A., Oakes, P. J., Reicher, S., \& Wetherell, M. S. (1987). Rediscovering the social group: A self-categorization theory. Oxford, UK: Basil Blackwell. 
Van Knippenberg, D., De Dreu, C. K. W., \& Homan, A. C. (2004). Work group diversity and group performance: an integrative model and research agenda. The Journal of Applied Psychology, 89, 1008-1022. doi: 10.1037/0021-9010.89.6.1008

Vezzali, L., Stathi, S., Crisp, R. J., \& Capozza, D. (2015). Comparing direct and imagined intergroup contact among children: Effects on outgroup stereotypes and helping intentions. International Journal of Intercultural Relations, 49, 46-53. doi: /10.1016/j.ijintrel.2015.06.009

Ward, T. B., Smith, S. M., \& Vaid, J. (1997). Conceptual structures and processes in creative thought. Washington, DC: APA. 
Table 1. Means of dependent variables in the four cells of the experimental design (standard deviations are reported in parentheses).

\section{Condition}

\begin{tabular}{|c|c|c|c|c|}
\hline Measure & $\begin{array}{c}\text { Diversity } \\
\text { present/ } \\
\text { Communal } \\
\text { mindset }\end{array}$ & $\begin{array}{c}\text { Diversity } \\
\text { present/ } \\
\text { Divisional } \\
\text { mindset }\end{array}$ & $\begin{array}{l}\text { Diversity } \\
\text { absent/ } \\
\text { Communal } \\
\text { mindset }\end{array}$ & $\begin{array}{c}\text { Diversity } \\
\text { absent/ } \\
\text { Divisional } \\
\text { mindset }\end{array}$ \\
\hline Creativity & $\begin{array}{c}0.58 \\
(0.07)\end{array}$ & $\begin{array}{c}0.54 \\
(0.08)\end{array}$ & $\begin{array}{c}0.50 \\
(0.12)\end{array}$ & $\begin{array}{c}0.53 \\
(0.12)\end{array}$ \\
\hline
\end{tabular}

Note. Creativity was square-root transformed to approximate normality; for ease of presentation, the mean and the standard deviation refer instead to nontransformed data. 